\title{
UPAYA PENINGKATAN KESEJAHTERAAN PELAKU UMKM DI KECAMATAN LAWANG DENGAN PEMBIAYAAN MUDHARABAH PADA BANK SYARIAH MANDIRI KCP LAWANG
}

\author{
Aslikhah \\ Universitas Yudharta Pasuruan \\ aslikhah@yudharta.ac.id
}

\begin{abstract}
Micro, Small and Medium Enterprises (MSMEs) have an important and strategic role in national economic development. In addition to playing a role in economic growth and employment, MSMEs also play a role in distributing development resultsThe purpose of this research is to find out how the efforts to improve the welfare of MSMEs actors in Lawang sub-district through Mudharabah financing at Bank Syari'ah Mandiri KCP Lawang. The method used in this research is the qualitative method. The data collection technique is by observing, interviewing and documenting the stakeholders fram Bank Syariah Mandiri KCP Lawang, as well as MSMEs actors who receive mudharabah financing from BSM KCP Lawang.The results of this study indicate that mudharabah financing at Bank Syariah Mandiri KCP Lawang has a fairly central contribution in improving the welfare of micro and small business actors which is characterized by the presence of new business actors each year. This is a benchmark for the success of mudharabah financing products in the community and as a benchmark for the success of a banking product in increasing the productivity of financing products.
\end{abstract}

Keywords: MSMEs, Mudharabah Financing, BSM KCP Lawang

Abstrak: Usaha Mikro, Kecil dan Menengah (UMKM) mempunyai peran penting dan strategis dalam pembangunan ekonomi nasional. Selain berperan dalam mendistribusikan hasilhasil pembangunan,pertumbuhan ekonomi dan penyerapan tenaga kerja, UMKM juga berperan dalam mendistribusikan hasil-hasil pembangunan.Tujuan dari penelitian ini adalah untuk mengetahui bagaimana upaya-upaya peningkatan kesejahteraan pelaku UMKM di kecamatan Lawang melalui pembiayaan Mudharabah pada Bank Syari'ah Mandiri KCP Lawang. Metode yang digunakan dalam penelitian ini adalah dengan metode kualitatif. Adapun teknik pengumpulan data dengan melakukan 
observasi,wawancara dan dokumentasi, baik pada stake holder yaitu pihak Bank Syariah Mandiri KCP Lawang, maupun pelaku yang menerima pembiayaan mudharabah dari BSM KCP Lawang. Hasil dari penelitian ini menunjukkan bahwa pembiayaan mudharabah di Bank Syariah Mandiri KCP Lawang memiliki kontribusi yang cukup sentral dalam meningkatkan kesejahteraan pelaku usaha mikro kecil dan menengah yang ditandai dengan adanya pelaku usaha baru setiap tahunnya. Hal tersebut merupakan sebuah tolak ukur keberhasilan produk pembiayaan mudharabah di kalangan masyarakat dan sebagai tolak ukur keberhasilan suatu produk perbankan dalam meningkatkan produktivitas produk pembiayaan.

Kata Kunci: Pelaku UMKM, Pembiayaan Mudharabah, BSM KCP Lawang

\section{PENDAHULUAN}

Usaha Mikro, Kecil dan Menengah (UMKM) mempunyai peran penting dan strategis dalam pembangunan ekonomi nasional. Selain berperan dalam pertumbuhan ekonomi dan penyerapan tenaga kerja, UMKM juga berperan dalam mendistribusikan hasil-hasil pembangunan. UMKM juga telah terbukti tidak terpengaruh terhadap krisis. Ketika krisis menerpa pada periode tahun 1997 - 1998, hanya UMKM yang mampu tetap berdiri kokoh. Data Badan Pusat Statistik memperlihatkan, pasca krisis ekonomi tahun 1997-1998 jumlah UMKM tidak berkurang, justru meningkat terus, bahkan mampu menyerap 85 juta hingga 107 juta tenaga kerja sampai tahun 2012. Pada tahun itu, jumlah pengusaha di Indonesia sebanyak 56.539.560 unit. Dari jumlah tersebut, Usaha Mikro Kecil dan Menengah (UMKM) sebanyak 56.534.592 unit atau 99.99\%. Sisanya, sekitar $0,01 \%$ atau 4.968 unit adalah usaha besar. Data tersebut membuktikan, UMKM merupakan pasar yang sangat potensial bagi industri jasa keuangan, terutama bank untuk menyalurkan pembiayaan. Karena sekitar 60 - 70\% pelaku UMKM belum memiliki akses pembiayaan perbankan.

Pengalaman tersebut telah menyadarkan banyak pihak, untuk memberikan porsi lebih besar terhadap bisnis skala mikro, kecil, dan menengah. Pemerintah dan legislatif membuktikan perhatiannya terhadap UMKM dengan meluncurkan UU No. 20 Tahun 2008 tentang UMKM. Dengan adanya peraturan yang menjadi payung hukum, gerak UMKM 
menjadi semakin leluasa. Persoalan klasik seperti akses permodalan kepada lembaga keuangan pun mulai bisa teratasi. Karena di dalam peraturan itu tercantum mengenai perluasan pendanaan dan fasilitasi oleh perbankan dan lembaga jasa keuangan non-bank. Perbankan pun mulai agresif menyalurkan kredit kepada UMKM. Bisnis UMKM tidak lagi dipandang sebagai bisnis kelas dua. Terbukti, penyaluran kredit ke sektor UMKM lambat laun mengalami pertumbuhan. Secara umum pertumbuhannya lebih tinggi dibandingkan total kredit perbankan. ${ }^{1}$

Bisnis UMKM menyumbang PDB (Produk Domestik Bruto) sekitar 60\% dan membuka lapangan pekerjaan bagi masyarakat.Selama tahun 2011 sampai 2012 terjadi pertumbuhan pada UMKM serta penurunan pada usaha besar. Bila pada tahun 2011, usaha besar mencapai 41,95\% tahun berikutnya hanya $40,92 \%$, turun sekitar $1,03 \%$. Pada UMKM terjadi sebaliknya. Bila usaha menengah pada tahun 2011 hanya 13,46\%, pada tahun 2012 mencapai $13,59 \%$. Ada peningkatan sebesar $0,13 \%$. Berbeda dengan usaha kecil, ada sedikit penurunan dari tahun 2011. Pada tahun itu mencapai 9,94\% namun pada tahun 2012 hanya mencapai 9,68\%, artinya menurun sekitar 0,26\%. Peningkatan cukup besar terjadi pada usaha mikro, bila tahun 2011 hanya mencapai 34,64\%, pada tahun 2012 berhasil meraih 38,81\% terjadi peningkatan sebesar $4,17 \% .^{2}$

Dari peranan penting dan strategis pelaku UMKM dalam pembangunan nasional serta dalam menyerap tenaga kerja yang ada di Indonesia khususnya di wilayah kecamatan Lawang Kabupaten Malang, penting untuk diteliti bagaimana upaya untuk meningkatkan kesejahteraan pelaku UMKM di kecamatan Lawang melalui pembiayaan mudharabah.

\section{KAJIAN TEORI}

\section{Pengertian UMKN}

Definisi UMKM diatur dalam Undang-Undang Republik Indonesia No.20 Tahun 2008 tentang UMKM. Pasal 1 dari UU tersebut, dinyatakan bahwa Usaha mikro adalah usaha produktif milik orang perorangan dan/atau badan usaha perorangan yang memiliki kriteria usaha mikro sebagaimana diatur dalam UU tersebut.

\footnotetext{
${ }^{1}$ Lembaga Pengembangan Perbankan Syari'ah (LIPI) BI, Profil Bisnis Usaha Mikro, Kecil dan Menengah, 2015. 1

${ }^{2}$ Lembaga Pengembangan Perbankan Syari'ah (LIPI) BI, Profil Bisnis Usaha Mikro, Kecil dan Menengah, 2015. 6
} 
Usaha kecil adalah usaha ekonomi produktif yang berdiri sendiri, yang dilakukan oleh orang perorangan atau badan usaha yang bukan merupakan anak perusahan atau bukan anak cabang yang dimiliki, dikuasai atau menjadi bagian, baik langsung maupun tidak langsung, dari usaha menengah atau usaha besar yang memenuhi kriteria usaha kecil sebagaimana dimaksud dalam UU tersebut ${ }^{3}$.

Sedangkan usaha mikro adalah usaha ekonomi produktif yang berdiri sendiri yang dilakukan oleh perorangan atau badan usaha yang bukan merupakan anak perusahaan atau bukan cabang perusahaan yang dimiliki, dikuasai, atau menjadi bagian baik langsung maupun tidak langsung, dari usaha mikro, usaha kecil atau usaha besar yang memenuhi kriteria usaha mikro sebagaimana dimaksud dalam UU tersebut.

Di dalam Undang - Undang tersebut, kriteria yang digunakan untuk mendefinisikan UMKM seperti yang tercantum dalam Pasal 6 adalah nilai kekayaan bersih atau nilai aset tidak termasuk tanah dan bangunan tempat usaha, atau hasil penjualan tahunan, dengan kriteria sebagai berikut:

a. Usaha mikro adalah unit usaha yang memiliki aset paling banyak $R p$ 50 juta tidak termasuk tanah dan bangunan tempat usaha dengan hasil penjualan tahunan paling besar Rp 300 juta.

b. Usaha kecil dengan nilai aset lebih dari Rp 50 juta sampai dengan paling banyak Rp 500 juta tidak termasuk tanah dan bangunan tempat usaha memiliki hasil penjualan tahunan lebih dari Rp 300 juta hingga maksimum Rp 2,5 M.

c. Usaha menengah adalah perusahaan dengan nilai kekayaan bersih lebih dari Rp 500 juta hingga paling banyak Rp 100 milyar hasil penjualan tahunan di atas $\mathrm{Rp} 2,5$ milyar sampai paling tinggi $\mathrm{Rp} 50$ milyar ${ }^{4}$.

Usaha Mikro Kecil dan Menengah (UMKM) dapat disebut sebagai tulang punggung perekonomian Indonesia apabila ditinjau dari kontribusinya terhadap indikator makro ekonomi seperti penyerapan tenaga kerja dan kontribusinya terhadap Produk Domestik Bruto (PDB). Data dari Kementerian Koperasi dan UKM pada tahun 2013 menunjukkan bahwa sektor UMKM mampu menyerap lebih dari 117 Juta

\footnotetext{
${ }^{3}$ Undang-Undang Republik Indonesia No.20 Tahun 2008.

${ }^{4}$ Undang-Undang Nomor tahun 2008 tentang UMKM, Bab IV pasal 6.
} 
tenaga Kerja. Di samping itu, sektor UMKM juga memberikan kontribusi sebesar $57.92 \%$ dari total PDB.

Salah satu kendala yang kerap terjadi dalam pengembangan sektor UMKM adalah kurangnya modal. Dari sisi pelaku UMKM, penyebab utama akses terhadap produk/jasa layanan keuangan yang rendah antara lain karena prosedur dan adminitrasi lembaga keuangan yang dianggap terlalu rumit. Sedangkan di lain pihak, lembaga keuangan juga masih menghadapi masalah bagaimana cara untuk menyalurkan modal mereka ke para pelaku usaha UMKM dengan aman (Karsidi, 2007).

Rendahnya akses masyarakat Indonesia terhadap produk/jasa layanan keuangan akses dapat tergambar melalui data Global Findex World Bank tahun 2014, di mana jumlah masyarakat dewasa Indonesia yang sudah memiliki rekening di lembaga keuangan (banked people) baru mencapai 36\% dari total penduduk dewasa. Secara global, ada 2 miliar penduduk dewasa di dunia yang belum memiliki rekening. Dalam hal ini, Indonesia menyumbang sebesar $6 \%$ dari 2 miliar tersebut yang penduduknya masih belum terlayani oleh perbankan. Tingginya jumlah unbanked people di Indonesia menjadi tantangan tersendiri bagi pemerintah maupun lembaga keuangan untuk menekan angka unbanked people dan mencapai masyarakat Indonesia yang lebih sejahtera, yang salah satu indikatornya adalah terciptanya kestabilan sistem keuangan.

Data yang dirilis oleh Global Financial Development Report (2014) menunjukkan bahwa faktor agama cukup memiliki kontribusi yang signifikan di negara-negara muslim sebagai penyebab unbanked. Adapun di Indonesia, resistensi terhadap perbankan dikarenakan faktor agama, berada di angka 1,5\%, jauh lebih rendah dari negara-negara muslim lain. Meski demikian, secara jumlah, penduduk yang enggan untuk memanfaatkan jasa perbankan karena faktor agama mencapai 2,1 juta penduduk. Adapun negara yang memiliki persentase tertinggi dalam penolakan terhadap perbankan adalah negara Afghanistan, yakni sebesar 33,6\%. (Global Findex World Bank, 2011).

Di sisi lain, pada tahun 2010 Indonesia merupakan negara dengan jumlah penduduk sebanyak 237.641.326 jiwa, di mana 87,2\% penduduknya beragama Islam (bps.go.id). Sampai dengan saat ini posisi Indonesia sebagai negara dengan potensi keuangan syariah berada di nomor urut 9 di dunia setelah Malaysia, Saudi Arabia, Iran, United Arab 
Emirates (UAE), Kuwait, Qatar, Bahrain, dan Turki. Kemudian berdasarkan kajian Earnst \& Young, bahwa global share of islamic finance banking asset Indonesia pada tahun 2015 menempati nomor tujuh dunia. $^{5}$

Keberadaan lembaga keuangan syariah khususnya perbankan merupakan alternatif jasa perbankan bagi kelompok masyarakat tertentu yang berpandangan bahwa lembaga keuangan konvensional bertentangan dengan keyakinan/ agamanya. Bukan hanya akibat kurangnya infrastruktur, alasan agama juga mengakibatkan tidak meratanya jangkauan akses layanan keuangan. Untuk itu, keuangan syariah berperan dalam membuka akses layanan keuangan yang lebih luas bagi mereka yang memiliki kecenderungan pada alasan agama.

Dengan banyaknya penduduk Indonesia yang mayoritas beragama Islam dan jumlah UMKM yang cukup signifikan maka keberadaan lembaga keuangan syariah seyogyanya dapat mengurangi angka unbanked people di Indonesia melalui pemanfaatan produk/ jasa keuangannya yang berdasarkan prinsip syariah sekaligus dapat meningkatkan tingkat kesejahteraan.

Dengan semakin banyaknya masyarakat yang melakukan akses terhadap lembaga keuangan maka dapat mendukung efektivitas transmisi kebijakan moneter, meningkatkan fungsi intermediasi lembaga keuangan khususnya perbankan, dan mengurangi peredaran jumlah uang kas (less cash society). Di lain sisi, peningkatan pemanfaatan layanan keuangan syariah bagi unbanked people juga diharapkan dapat meningkatkan pangsa pasar perbankan syariah. ${ }^{6}$

\section{Pengertian Mudharabah}

Pada umumnya kata mudharabah berasal dari kata dharb, yang berarti memukul atau berjalan. Pengertian dari memukul atau berjalan diatas yang maksudnya adalah proses seseorang memukulkan kakinya dalam menjalankan usahanya ${ }^{7}$.

\footnotetext{
${ }^{5}$ Bank Indonesia, Pilot Project Peningkatan Akses Keuangan Kelompok Masyarakat atau Pelaku Usaha Melalui Pemanfaatan Product/ Jasa Layanan Keuangan Syari'ah, 2017.2

${ }^{6}$ Ibid, Bank Indonesia, Pilot Project.

${ }^{7}$ Muhammad, Manajemen Pembiayaan Bank Syari'ah ( Yogyakarta: Akademi Manajemen Perusahaan YKPN. 2005), 102.
} 
Sedangkan pengertian mudharabah yang secara teknis adalah suatu akad kerja sama untuk suatu usaha antara dua belah pihak dimana pihak yang pertama (shahibul maal) menyediakan seluruh modalnya dan sedangkan pihak yang lain menjadi pengelolanya ${ }^{8}$. Keuntungan dari usahanya tersebut secara mudharabah akan dibagi hasilnya menurut kesepakatan yang telah disepakati pada perjanjian awal, dan apabila usaha tersebut mengalami kerugian maka kerugian tersebut akan ditanggung oleh pihak pemodal selama kerugian tersebut bukan disebabkan kelalaian pengelola modal. Dan jika kerugian tersebut disebabkan karena kecurangan atau kelalaian pengelola modal, maka pengelola modal yang harus bertanggung jawab atas kerugian yang telah dialaminya.

Pengertian mudharabah secara definisi adalah suatu bentuk perniagaan dimana pemilik modal (shahibul maal) menyetorkan modalnya kepada seorang pengusaha yang sering disebut dengan (mudharib), untuk diniagakan dengan keuntungan yang akan dibagi bersama sesuai dengan kesepakatan dari kedua belah pihak sedangkan terdapat kerugian akan ditanggung oleh pemilik modal jika disebabkan olehnya, dan jika disebabkan oleh pengelola modal maka pengelola modal yang harus menanggung kerugian tersebut.

Pada hakikatnya pengertian dari mudharabah adalah suatu bentuk kerja sama antara shohibul maal dan mudhorib, dimana dana $100 \%$ dari shohibul maal. Sedangkan mudhorib hanya sebagai pengelola yang keuntungannya akan dibagi sesuai dengan kesepakatan yang telah disepakati di awal. Mudharabah adalah salah satu akad kerja sama kemitraan berdasarkan prinsip berbagi untung dan rugi (profit and loss sharing principle), dilakukan sekurang-kurangnya oleh dua pihak, dimana yang pertama memiliki dan menyediakan modal, disebut shohibul maal, sedang ke dua memiliki keahlian dan bertanggung jawab atas pengelolaan dana / menejemen usaha halal tertentu, disebut mudhorib $^{9}$.

\footnotetext{
${ }^{8}$ Muhammad Syafi'i Antonio, Bank Syari'ah: Dari Teori ke Praktik (Jakarta: Gema Insani Press. 2001), 95.

${ }^{9}$ Makhalul ilmi SM, Teori Dan Praktik Lembaga Mikro Keuangan Syari'ah (Yogyakarta: UII press Yogyakarta, 2002), 32.
} 


\section{Aplikasi Mudharabah Dalam Perbankan}

Mudharabah dalam perbankan syari'ah biasanya diterapkan pada produk-produk pembiayaan dan pendanaan. Sedangkan pada sisi penghimpunan dana mudharabah diterapkan pada ${ }^{10}$ :

a. Tabungan berjangka, yaitu tabungan yang dimaksudkan untuk tujuan khusus, yaitu seperti tabungan haji, dan tabungan kurban, dan sebagainya;

b. Deposito biasa dan spesial, diposito spesial (special investment), dimana dana yang dititipkan nasabah, khusus untuk bisnis tertentu, misalnya saja dalam murabahah ataupun ijarah saja. untuk $^{11}$ :

Sedangkan pada sisi pembiayaan, mudharabah diterapkan

a. Pembiayaan modal kerja, seperti modal kerja perdagangan dan jasa

b. Investasi khusus, disebut juga mudharabah muqayyadah, dimana sumber dana khusus dengan penyaluran yang khusus dengan syarat syarat yang telah ditetapkan oleh shahibul maal.

Mudharabah juga dapat dilakukan dengan memisahkan atau mencampurkan dana mudharabah. Seperti dalam penjelasan dibawah ini, yaitu $^{12}$ :

a. Dana harta-harta lainnya, pemisahan total antara dana mudharabah termasuk harta mudharib.

Teknik ini memiliki kelebihan dan kekurangan, kelebihan dari teknik ini ialah bahwa pendapatan dan biaya dapat dipisahkan dari masing-masing dana dan dapat dihitung dengan tepat. Selain itu, keuntungan atau kerugian dapat dihitung dan dialokasikan dengan benar. Sedangkan kekurangan teknik ini terutama menyangkut masalah "moral hazard" yang sering diartikan sebagai ketidakjujuran atau kejahatan dibidang asuransi.

b. Dana mudharabah dicampur dan disatukan dengan sumber-sumber dana lainnya.

\footnotetext{
${ }^{10}$ Muhammad Syafi'i Antonio, Bank Syari'ah: Dari Teori Ke Praktik (Jakarta: Gema Insani Press, 2001), 97.

${ }^{11}$ Ibid., 97.

${ }^{12}$ Muhammad, Manajemen Bank Syari'ah ( Yogyakarta: UPP AMP YKPN, 2002), 109.
} 


\section{METODOLOGI}

1. Pendekatan dan Jenis Penelitian

Penelitian ini menggunakan metode kualitatif. Penelitian kualitatif adalah penelitian untuk memahami fenomena tentang apa yang dialami oleh subjek penelitian misalkan perilaku dan tindakan secara holistik ${ }^{13}$.

Dalam metode ini penelitian yang dimaksudkan untuk membuat deskripsi mengenai situasi situasi atau kejadian kejadian ${ }^{14}$. Pendekatan yang digunakan adalah pendekatan empiris, yaitu subjek kajian dengan melakukan pengamatan langsung ke lapangan.

2. Kehadiran Peneliti

Dalam penelitian ini, pada waktu mengumpulkan data di lapangan, peneliti berperan serta pada situs penelitian dan mengikuti secara aktif kegiatan kegiatan di lapangan ${ }^{15}$.

3. Sumber Data

a. Data Primer

Data primer merupakan sumber data yang diperoleh secara langsung dari objek yang diteliti. Menurut Sugiyono (2010:137) menyatakan bahwa sumber data primer adalah sumber data yang langsung memberikan data kepada pengumpul data. Teknik pengambilan data primer pada penelitian ini dilakukan dengan cara wawancara dengan pihak perusahaan baik itu kepala cabang atau unsur pimpinan maupun staff perusahaan tersebut.

b. Data Sekunder

Data Sekunder adalah teknik pengumpulan data berupa riset yaitu pengumpulan data yang dilakukan dengan cara membaca bukubuku, jurnal, data badan pusat statistik, dan sumber-sumber lain yang berkaitan dengan judul penelitian yang dimaksud ${ }^{16}$. Sumber data dalam penelitian ini meliputi data dari website Pemerintah Kabupaten Malang, websiteperusahaan, Badan Pusat Statistik dan Undang Undang di Indonesia yang mengatur tentang Usaha Mikro Kecil dan Menengah (UMKM).

\footnotetext{
${ }^{13}$ Lexy J. Moleong, Metode Penelitian Kualitatif (Bandung: Remaja Rosda Karya, 2011), 6.

${ }^{14}$ Sumadi Suryabrata, Metodologi Penelitian (Jakarta: PT. RajaGrafindo, 2004), 76.

${ }^{15}$ Moleong, Metode Penelitian Kualitatif..., 9.

${ }^{16}$ Kartini Kartono, Pengantar Metedologi Riset Sosial (Bandung: Mandar Maju, 2012), 185.
} 
4. Prosedur Pengumpulan Data

Dalam prosedur pengumpulan data, penulis menggunakan beberapa metode sebagai berikut :

a. Observasi

Observasi merupakan kegiatan pengumpulan data dengan melakukan pengamatan langsung atas kondisi lingkungan objek penelitian. Kegiatan observasi ini dimulai dari melakukan pemilahan, pengubahan, pencatatan, pengodean hingga dapat mencapai tujuan penelitian secara empiris misalnya untuk menguji teori. ${ }^{17}$

Observasi dilakukan di Bank Syariah Mandiri KCP Lawang. Langkah awal peneliti yaitu observasi untuk mencari dan mengumpulkan data terkait dengan penelitian yang kemudian data diolah dan disajikan menjadi suatu informasi yang jelas agar dapat dipahami oleh pembaca.

b. Wawancara

Pada penelitian ini, peneliti melakukan wawancara secara langsung dengan pihak Bank Syariah Mandiri KCP Lawang. Wawancara dilakukan untuk memperoleh data ataupun informasi terkait dengan pembiayaan mudharabah, dan pengaruhnya terhadap kesejahteraan bagi pelaku UMKM sekitar.

c. Dokumentasi

Dokumentasi adalah mencari data-data mengenai hal-hal atau variabel yang merupakan catatan buku, surat kabar, prasasti, notulen rapat, agenda dan lain sebagainya. Dokumen merupakan catatan atau karya seseorang tentang sesuatu yang sudah berlalu. Dokumen tentang orang atau sekelompok orang, peristiwa, atau kejadian dalam situasi sosial yang sesuai dan terkait dengan fokus penelitian. Dokumen itu dapat berbentuk teks tertulis, gambar maupun foto ${ }^{18}$.

${ }^{17}$ Siregar, Metode Penelitian Kuantitatif : Dilengkapi Dengan Perbandingan Perhitungan Manual \& SPSS (Jakarta : Penerbit Kencana Prenada Media Grup, 2013), 19.

${ }^{18}$ A Muri Yusuf, Metode penelitian Kuantitatif, Kualitatif dan Penelitian Gabungan (Jakarta : Kencan, 2017), 391. 


\section{PEMBAHASAN}

\section{Peningkatan kesejahteraan Pelaku UMKM dengan adanya pembiayaan mudharabah di BSM KCP Lawang.}

\section{Tabel 1}

Perkembangan pembiayaan mudharabah di Bank Syariah Mandiri KCP Lawang dalam empat tahun terakhir

\begin{tabular}{|c|c|}
\hline Tahun & Jumlah nasabah \\
\hline 2015 & 14 orang \\
\hline 2016 & 13 orang \\
\hline 2017 & 39 orang \\
\hline 2018 & 57 orang \\
\hline
\end{tabular}

Sumber : Data Nasabah Warung Mikro tahun 2015 - 2018

Berdasarkan Tabel 4.1 diatas, perkembangan kontribusi pembiayaan mudharabah Bank Syariah Mandiri KCP Lawang tahun 2015 - 2018 secara umum lebih meningkat meskipun ditahun 2016 mengalami penurunan. Tercatat tahun 2015 ada sekitar 14 orang yang menggunakan jasa pembiayaan mudharabah. Kemudian ditahun 2016 mengalami penurunan 1 orang atau sekitar $0.69 \%$ kemudian pada tahun 2017 mengalami kenaikan yang cukup drastis dari 13 orang menjadi 39 orang artinya ada kenaikan sebesar $18,06 \%$ dari tahun 2016. Lalu ditahun berikutnya meningkat dari 39 orang menjadi 57 orang atau meningkat sekitar $12,49 \%$ dari tahun sebelumnya.

Dari hasil temuan diatas, produk pembiayaan mudharabah masih memiliki peran yang cukup sentral untuk meningkatkan kesejahteraan pelaku usaha meskipun di tahun 2019 produk tersebut mengalami penurunan yang cukup drastis yang sebagian disebabkan oleh nasabah yang beralih menggunakan produk pembiayaan murabahah. Namun pada tahun 2019 masih ada kemungkinan nasabah yang menggunakan produk tersebut dapat bertambah sampai dengan akhir tahun 2019.

Menurut Bapak Dhony selaku Micro Analist di Bank Syariah Mandiri KCP Lawang faktor pertimbangan dalam memberikan pembiayaan yaitu:

a. Karakternya. Apakah karakternya pekerja keras atau pemalas dan lain sebagainya harus diketahui secara detail

b. Kapasitas dalam pembayaran. Kemampuan dia dalam pembayaran cicilan setiap bulannya dapat disesuaikan dengan pendapatan 
$270\}\{$ Upaya Peningkatan Kesejahteraan Pelaku UMKM

c. Kepercayaan. Dapat dilihat dari segi karakter apakah orang tersebut amanah atau tidak harus diketahui oleh micro analist ${ }^{19}$.

Sedangkan menurut Bapak Ady selaku Micro Finance Sales di Bank Syariah Mandiri KCP Lawang faktor pertimbangan dalam memberikan pembiayaan yaitu:

a. Melihat dari Jaminan. Jaminan yang dijaminkan nasabah ke pada pihak Bank harus sesuai dengan pengajuan pembiayaan

b. Melihat dari kondisi usaha

c. Melihat kapasitas modal yang dimiliki oleh nasabah ${ }^{20}$

Dari hasil tersebut dapat disimpulkan bahwa dalam melakukan pengajuan pembiayaan, bank memiliki 6 faktor pertimbangan dalam memberikan pembiayaan kepada nasabah.

a. Karakter

Karakter adalah sifat atau watak seseorang. Sifat atau watak dari seseorang yang akan diberikan kredit benar-benar harus dipercaya. Dalam hal ini bank meyakini benar bahwa calon debiturnya memiliki reputasi baik, artinya selalu menepati janji dan tidak terlibat hal-hal yang berkaitan dengan kriminalitas, misalnya penjudi, pemabuk, atau penipu.

b. Kapasitas

Kapasitas adalah analisis untuk mengetahui kemampuan nasabah dalam membayar kredit. Bank harus mengetahui secara pasti atas kemampuan calon debitur dengan melakukan analisis usahanya dari waktu ke waktu.

c. Modal

Modal adalah kondisi kekayaan yang dimiliki oleh nasabah. Bank harus meneliti modal calon debitur selain besarnya juga strukturnya. Untuk melihat penggunaan modal apakah efektif, dapat dilihat dari laporan keuangan (neraca dan laporan rugi laba) yang disajikan.

d. Kondisi Ekonomi

Pembiayaan yang diberikan juga perlu mempertimbangkan kondisi ekonomi yang dikaitkan dengan prospek usaha calon

${ }^{19}$ Dhony, Micro Analist Bank Syariah Mandiri KCP Lawang, Wawancara, Lawang, 1 Juli 2019.

${ }^{20}$ Ady, Micro Finance Sales Bank Syariah Mandiri KCP Lawang, Wawancara, Lawang, 1 Juli 2019 
nasabah. Penilaian kondisi dan bidang usaha yang dibiayai hendaknya benar-benar memiliki prospek yang baik, sehingga kemungkinan kredit tersebut bermasalah relatif kecil.

e. Jaminan

Jaminan merupakan suatu barang yang diberikan calon nasabah baik yang bersifat fisik maupun yang nonfisik. Jaminan hendaknya melebihi jumlah kredit yang diberikan. Jaminan juga harus diteliti keabsahannya, sehingga jika terjadi sesuatu, maka jaminan yang dititipkan akan dapat dipergunakan secepat mungkin.

f. Kepercayaan

Kepercayaan menjadi sesuatu hal yang penting dalam pelaksanaan akad pembiayaan. Karena dengan kepercayaan suatu perjanjian dapat berjalan sebagaimana mestinya tanpa adanya kendala.

g. Penentuan Nilai Taksiran Jaminan

Dalam melakukan pembiayaan mudharabah tentu saja besaran dana yang akan diberikan Bank Syariah Mandiri KCP Lawang kepada nasabah harus disesuaikan dengan besaran nilai taksiran jaminan yang akan diberikan nasabah kepada Bank Syariah Mandiri KCP Lawang. Berikut nilai standart taksiran barang yang ditetapkan oleh Bank Syariah Mandiri KCP Lawang.

Tabel 2

Taksiran Standart Jaminan

\begin{tabular}{|l|l|}
\hline \multicolumn{1}{|c|}{ Jenis Jaminan } & \multicolumn{1}{c|}{ Standart Taksiran Pembiayaan } \\
\hline Kendaraan bermotor & Maksimal 70\% dari harga beli \\
\hline Rumah (Bersertifikat IMB) & Maksiman 80\% dari harga beli \\
\hline Rumah tanpa sertifikat & Maksimal 50\% dari harga beli \\
\hline
\end{tabular}

\section{Perhitungan Pembiayaan Modal Usaha beserta Jangka Waktunya}

Berikut adalah cara perhitungan pembiayaan untuk modal usaha yang ada di Bank Syariah Mandiri KCP Lawang

Contoh Kasus :

Pak Budi memiliki rencana untuk memperbesar usahanya. namun Pak Budi hanya memiliki dana sebesar Rp 50.000.000 sedangkan total biaya yang digunakan untuk memperbesar usahanya ditaksir sekitar $\mathrm{Rp}$ 
$272\}\{$ Upaya Peningkatan Kesejahteraan Pelaku UMKM

150.000.000. Akhirnya Pak Budi mengajukan pembiayaan ke Bank Syariah Mandiri KCP Lawang sebesar Rp 100.000.000

Maka penjabaran perhitungannya sebagai berikut :

Pokok pencairan : : Rp 100.000 .000

Margin : : $1,04 \%$ perbulan*

(Besaran margin sesuai dengan ketentuan perusahaan)

Jangka Waktu : 4 tahun / 48 bulan

Margin 4 tahun $\quad: 1,04 \%$ perbulan

: Rp 1.067.274.43 / bulan x 48 bulan

: Rp 51.229.173

Total

: Angsuran pokok + Margin

: Rp 100.000.000 + Rp 51.229.173

: Rp 151.229.173

Angsuran per bulan : Rp 151.229.173 : 48 bulan

: Rp 3.150.608

Berikut kisaran angsuran yang harus dibayarkan nasabah kepada bank jika melakukan pembiayaan

Tabel 3

Angsuran

\begin{tabular}{|c|c|c|c|c|}
\hline \multirow{2}{*}{ Nominal } & \multicolumn{4}{|c|}{ Angsuran per Bulan (Rupiah) } \\
\cline { 2 - 5 } & 12 & 24 & 36 & 48 \\
\hline 11.000 .000 & 1.040 .156 & 581.582 & 431.561 & \\
\hline 20.000 .000 & 1.891 .192 & 1.057 .422 & 784.657 & \\
\hline 25.000 .000 & 2.363 .990 & 1.321 .777 & 980.821 & \\
\hline 30.000 .000 & 2.836 .788 & 1.586 .133 & 1.176 .986 & \\
\hline 40.000 .000 & 3.782 .384 & 2.114 .844 & 1.569 .314 & \\
\hline 50.000 .000 & 4.727 .980 & 2.643 .555 & 1.961 .643 & \\
\hline 60.000 .000 & 5.615 .663 & 3.112 .689 & 2.291 .427 & 1.890 .365 \\
\hline 70.000 .000 & 6.551 .607 & 3.631 .471 & 2.673 .332 & 2.025 .425 \\
\hline 80.000 .000 & 7.487 .550 & 4.150 .252 & 3.055 .236 & 2.520 .486 \\
\hline 90.000 .000 & 8.423 .494 & 4.669 .034 & 3.437 .141 & 2.835 .547 \\
\hline 100.000 .000 & 9.359 .438 & 5.187 .815 & 3.819 .045 & 3.150 .608 \\
\hline 110.000 .000 & 10.189 .796 & 5.598 .538 & 4.087 .994 & 3.347 .340 \\
\hline 120.000 .000 & 11.116 .141 & 6.107 .496 & 4.459 .630 & 3.651 .643 \\
\hline 130.000 .000 & 12.042 .486 & 6.616 .454 & 4.831 .266 & 3.955 .947 \\
\hline
\end{tabular}

Malia: Jurnal Ekonomi Islam, Volume 11 Nomor 2 Juni 2020 :::.. 


\begin{tabular}{|l|l|l|l|l|}
\hline 140.000 .000 & 12.968 .831 & 7.125 .412 & 5.202 .902 & 4.260 .251 \\
\hline 150.000 .000 & 13.895 .176 & 7.634 .370 & 5.574 .538 & 4.564 .554 \\
\hline 160.000 .000 & 14.821 .521 & 8.143 .328 & 5.946 .173 & 4.868 .858 \\
\hline 170.000 .000 & 15.747 .866 & 8.652 .286 & 6.317 .809 & 5.173 .162 \\
\hline 180.000 .000 & 16.674 .211 & 9.161 .244 & 6.689 .445 & 5.477 .465 \\
\hline 190.000 .000 & 17.600 .556 & 9.670 .203 & 7.061 .081 & 5.781 .769 \\
\hline 200.000 .000 & 18.526 .901 & 10.179 .161 & 7.432 .717 & 6.086 .072 \\
\hline
\end{tabular}

Sumber : Warung Mikro Bank Syariah Mandiri KCP Lawang

Jangka waktu maksimal dalam pembiayaan di Bank Syariah Mandiri KCP Lawang terbagi menjadi 2 macam yaitu

a. Jika tujuannya untuk modal kerja atau usaha, maka jangka waktu maksimalnya adalah 4 tahun

b. Jika tujuannya untuk investasi, semisal membeli rumah atau membeli tanah dll, maka jangka waktu maksimalnya adalah 5 tahun

Dalam memberikan dana pembiayaan tentu ada pihak bank yang mengawasi atau mengontrol nasabah yang melakukan pembiayaan agar perjanjian tersebut dapat berjalan sesuai akad perjanjian. Menurut Dhony selaku Micro Analist Bank Syariah Mandiri KCP Lawang mengatakan bahwa mengontrol nasabah yang melakukan pembiayaan yaitu dengan cara menelpon nasabah untuk mengetahui perkembangan usaha yang dijalankan. Kemudian untuk mengontrol waktu jatuh tempo pembayaran biasanya nasabah akan dihubungi by phone atau pihak bank akan mengirim pesan singkat untuk mengingatkan nasabah bahwasannya jatuh tempo pembayaran kurang beberapa hari lagi.

Sedangkan menurut Bapak Ady selaku Micro Finance Sales dari Bank Syariah Mandiri KCP Lawang, cara mengontrol nasabah yang dilakukan yaitu sebelum dua hari jatuh tempo pembayaran biasanya beliau menelpon untuk mengingatkan bahwa waktu pembayaran sebentar lagi harus dibayarkan. Untuk cara mengontrol usaha itu sendiri biasanya dikontrol ke tempat nasabah yang bersangkutan guna memastikan bahwa nasabah menjalankan usaha sebagaimana mestinya.

Dalam hal ini juga dijelaskan bahwa jatuh tempo pembayaran memiliki beberapa kebijakan yang sudah dibuat dan ditetapkan oleh pihak Bank Syariah Mandiri KCP Lawang. Apabila melebihi batas waktu yang ditentukan, maka kebijakan yang diambil dari Bank Syariah Mandiri KCP Lawang yaitu : 
$274\}\{$ Upaya Peningkatan Kesejahteraan Pelaku UMKM

a. Apabila terlambat bayar pada bulan pertama maka Bank Syariah Mandiri KCP Lawang akan memberikan surat peringatan yang pertama

b. Apabila terlambat bayar pada bulan kedua maka Bank Syariah Mandiri KCP Lawang akan memberikan surat peringatan yang kedua

c. Apabila terlambat bayar pada bulan ketiga maka Bank Syariah Mandiri KCP Lawang akan memberikan surat peringatan yang ketiga

d. Apabila terlambat bulan keempat nasabah akan diberikan kesempatan untuk menjual barang jaminannya secara sukarela (nasabahnya sendiri yang menjual barangnya)

e. Apabila bulan kelima nasabah masih belum bisa membayar, pihak Bank Syariah Mandiri KCP Lawang akan memberikan surat pemberitahuan lelang

Sesuai dengan kebijakan di Bank Syariah Mandiri KCP Lawang apabila tahapan-tahapan diatas sudah dilakukan, Bank Syariah masih menunggu sampai barang dilelang laku. Sambil barang jaminannya dilelang, penagihan tetap harus berjalan sampai barangnya laku guna untuk menutupi biaya pengajuan pembiayaan mudharabah di Bank Syariah Mandiri KCP Lawang ${ }^{21}$.

\section{KESIMPULAN}

Berdasarkan uraian-uraian yang telah diungkapkan pada pembahasan, maka dapat diambil beberapa kesimpulan sebagai jawaban atas pokok permasalahan yang diajukan dalam penelitian ini, yaitu:

1. Mekanisme pembiayaan mudharabah di Bank Syariah Mandiri KCP Lawang yaitu nasabah harus memenuhi persyaratan dan mengikuti alur prosedur yang sudah ditetapkan oleh pihak Bank Setelah nasabah memenuhi persyaratan, nasabah harus mengikuti alur prosedur pembiayaan.

2. Pembiayaan mudharabah di Bank Syariah Mandiri KCP Lawang memiliki kontribusi yang cukup sentral dalam meningkatkan kesejahteraan pelaku usaha mikro kecil dan menengah yang ditandai dengan adanya pelaku usaha baru setiap tahunnya. Hal tersebut merupakan sebuah tolak ukur keberhasilan produk pembiayaan

\footnotetext{
${ }^{21}$ Dhony selaku Micro Analist Bank Syariah Mandiri KCP Lawang, Wawancara, Lawang, 1 Juli 2019
} 
mudharabah dikalangan masyarakat dan sebagai tolak ukur keberhasilan suatu produk perbankan dalam meningkatkan produktivitas produk pembiayaan.

\section{DAFTAR PUSTAKA}

Badan Pusat Statistik 2017.

Bank Indonesia, Pilot Project Peningkatan Akses Keuangan Kelompok Masyarakat atau Pelaku Usaha Melalui Pemanfaatan Product/Jasa Layanan Keuangan Syari'ah. 2017.

Faturochman. 2012. Kesejahteraan Masyarakat. Yogyakarta: Pustaka Belajar.

https://www.syariahmandiri.co.id/tentang-kami/profil-perusahaan/ (Rabu, 3 Juli 2019, 10.40)

Juhaya, Praja, S. 1995. Filsafat Hukum Islam. Bandung: LPPM Universitas Islam Bandung.

Kartono, Kartini. 2012. Pengantar Metodologi Riset Sosial. Bandung: Mandar Maju.

Lembaga Pengembangan Perbankan Syari'ah (LIPI) BI, Profil Bisnis Usaha Mikro, Kecil dan Menengah, 2015.

Moleong, Lexy J. 2011. Metode Penelitian Kualitatif. Bandung: Remaja Rosda Karya.

Muhammad. 2002. Manajemen Bank Syari'ah. Yogyakarta: UPP AMP YKPN.

Siregar. 2013. Metode Penelitian Kuantitatif: Dilengkapi Dengan Perbandingan Perhitungan Manual dan SPSS. Jakarta: Penerbit Kencana Prenada Media.

Suryabrata, Sumadi. 2004. Metodologi Penelitian. Jakarta: PT Raja Grafindo. Syafi'I Antonio, Muhammad. 2001. Bank Syariah: Dari Teori ke Praktik. Jakarta: Gema Insani Press.

Tohar, M. 2000. Membuka Usaha Kecil. Yogyakarta: Kanisius.

Undang Undang Republik Indonesia Tahun 2008 tentang UMKM Bab IV Pasal 6.

Yusuf, Muri. 2017. Metode Penelitian Kuantitatif, Kualitatif dan Penelitian Gabungan. Jakarta: Kencan. 
$276\}\{$ Upaya Peningkatan Kesejahteraan Pelaku UMKM

..::: Malia: Jurnal Ekonomi Islam, Volume 11 Nomor 2 Juni 2020 :::.. 